\title{
Not Just Efficiency: Insolvency Law in the EU and Its Political Dimension
}

\section{Federico M. Mucciarelli*}

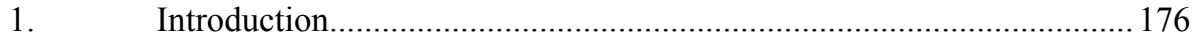

2. Goals and political economy of corporate insolvency law .................... 178

2.1 Goals of insolvency law................................................................... 178

2.2 Creditors' priorities and the redistributive function of insolvency

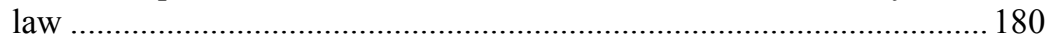

$2.3 \quad$ Political economy of insolvency law ................................................ 183

3. Insolvency law in the EU: from the goal to avoid forum shopping to a chaotic choice model................................................................... 185

3.1 Exceptions to the powers of the state of the COMI ............................ 185

3.2 Corporate mobility and regulatory arbitrage regarding insolvency

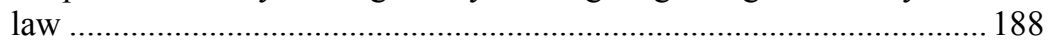

4. The reform of the Insolvency Regulation and its political dimension ... 191

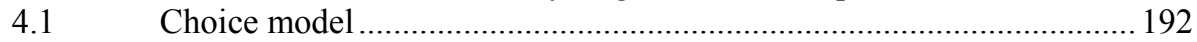

4.1.1 The case for the choice model in the European Union ......................... 192

4.1.2 Drawbacks of the choice model ............................................................ 193

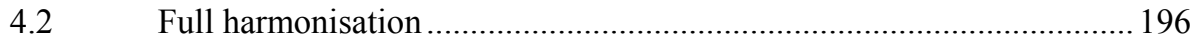

4.2.1 The case for harmonising insolvency law in the European Union......... 196

4.2.2 Drawbacks of full harmonisation..................................................... 197

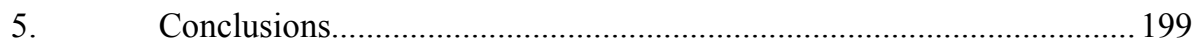

\begin{abstract}
Certain insolvency law rules, like creditors' priorities and set-off rights, have a distributive impact on creditors. Distributional rules reflect the hierarchies of values and interests in each jurisdiction and, as a result, have high political relevance and pose an obstacle to reforming the EU Insolvency Regulation. This paper
\end{abstract}

* University of London, SOAS, and University of Modena and Reggio Emilia, Department of Economics and CEFIN. An earlier version of this paper was presented at the Global Fellows Forum, NYU Law School, 3 February 2011. I owe special thanks to Marcel Kahan for many inspiring comments and suggestions regarding previous versions of the paper. I would like to thank Carlos J. Closa, Luca Enriques, Troy McKenzie, Christoph Paulus, Arthur Pinto, Maxi Charlotte Scherer, Ingo Venzke, Marc-Philippe Weller and Tal Zarsky for their helpful comments on the version of this paper presented at NYU Law School, and all participants in the Global Fellows Forum for their contribution to the discussion. All errors and opinions are the author's. 
will show the difficulty of reform by addressing two alternative options to regulate cross-border insolvencies in the European Union. The first one is the 'choice model', under which companies can select the insolvency law they prefer. Although such a model would allow distressed firms to select the most efficient insolvency law, it would also displace Member States' power to protect local constituencies. The choice model therefore produces negative externalities and raises legitimacy concerns. The opposite solution is full harmonisation of insolvency law at EU level, including distributional rules. Full harmonisation would have the advantage of internalising all externalities produced by cross-border insolvencies. However, the EU legislative process, which is still based on negotiations between states, is not apt to decide on distributive insolvency rules; additionally, if harmonisation includes such rules, it will indirectly modify national social security strategies and equilibria. This debate shows that the choice regarding power allocation over bankruptcies in the EU depends on the progress of European integration and is mainly a matter of political legitimacy, not only of efficiency.

Keywords: insolvency law, COMI, forum shopping, harmonisation, political legitimacy.

\section{1.}

\section{INTRODUCTION}

With the development of trade and the economic integration of supranational territories, cross-border insolvencies become increasingly important. Indeed, insolvent companies can have assets and creditors in a number of states, each of which may claim to be competent to govern the insolvency proceedings or, at least, to liquidate domestic assets and protect local creditors. Therefore, the question of jurisdiction for insolvency cases as well as the power of such regulators is becoming a central issue in the international arena.

This issue also emerges within the European Union, where firms are increasingly active as in a single market. To provide guidance on insolvency proceedings, the EU Insolvency Regulation of $2000^{1}$ was enacted with the aim to coordinate Member States' laws and courts' authority. The fundamental idea of the Insolvency Regulation is that the Member State where a debtor has its 'centre of main interests' (hereinafter 'COMI') should be competent to regulate its main insolvency proceedings and that these proceedings should have universal effect in all Member States.

In recent years, the European Parliament raised the question of harmonising the substantive insolvency laws in the EU to cope with the continental dimension of many companies. The first effort was to request Insol Europe, the association of

1 Council Regulation (EC) No 1346/2000 of 29 May 2000, OJ 2000 L 160/1, 30 June 2000. The Insolvency Regulation does not apply to Denmark: Recital 33 Insolvency Regulation. 
European insolvency practitioners and scholars, to deliver a report on the feasibility of such harmonisation (hereinafter 'Insol Report'). ${ }^{2}$ The Report was published in April 2010 and, following a careful comparative overview of Member States' legislations, suggested harmonising a significant portion of insolvency law. The Insol Report argued that the differences in insolvency rules between Member States incentivise firms to undertake so-called 'forum shopping', that is, to seek the most convenient insolvency law and venue regardless of the location of their assets and activities. According to the Report, forum shopping jeopardises transparency and legal predictability and decreases the chances to restructure insolvent firms. ${ }^{3}$

In response to the Insol Report, the European Parliament adopted a Resolution requesting the Commission to submit one or more legislative proposals aimed at partially harmonising insolvency law in the European Union and at amending the Insolvency Regulation. ${ }^{4}$ Consequently, the European Parliament proposed to partially harmonise the following issues: (a) opening of insolvency proceedings; ${ }^{5}$ (b) rules on the filing and verification of claims; ${ }^{6}$ (c) avoidance of fraudulent and preference transfers; ${ }^{7}$ (d) restructuring plans $;^{8}$ and (e) insolvencies of groups of companies. ${ }^{9}$

2 The Insol Report is available at: <http://www.europarl.europa.eu/activities/committees/ studies/searchPerform.do>.

3 Ibid., at pp. 26-27.

4 European Parliament Resolution, with recommendations to the Commission on insolvency proceedings in the context of EU company law (2011/2006(INI)), 15.11.2011 (hereinafter, 'European Parliament Resolution'). The legal basis of such harmonisation is uncertain and the Resolution proposes three alternatives: (1) Article 50 of the Treaty on the Functioning of the European Union (hereinafter, 'TFEU'), which allows the Parliament and the Council to enact harmonisation directives to attain freedom of establishment throughout the EU; (2) Article 81 TFEU, pursuant to which the Union can adopt measures for the approximation of Member States' laws regarding judicial cooperation in civil matters with cross-borders implications; (3) Article 114 TFEU, pursuant to which harmonising measures can be enacted with the aim to establish the internal market. On the legal basis for insolvency law harmonisation, see Bob Wessels, 'Harmonization of Insolvency Law in Europe', 8 European Company Law (2011) p. 27, and Bob Wessels and Ian Fletcher, Harmonisation of Insolvency Law in Europe (Deventer, Kluwer 2012), at pp. 49-65.

5 European Parliament Resolution, supra n. 4, § 1.1. See also Insol Report, supra n. 2, at pp. 9-12, and Anna Maria Pukzsto, Harmonisation of Insolvency Law at EU Level with Respect to Opening of Proceedings, Claims Filing and Verification and Reorganisation Plans (2011), available at: <http://www.europarl.europa.eu/document/activities/cont/201106/20110622ATT 22313/20110622ATT22313EN.pdf $>$.

${ }^{6}$ European Parliament Resolution, supra n. 4, § 1.2. See also Insol Report, supra n. 2, at pp. 15-16.

7 European Parliament Resolution supra n. 4, § 1.3; Insol Report, supra n. 2, at pp. 18-20; see also Daniel Fritz, Harmonisation of Insolvency Law at EU level: Avoidance Actions and Rules on Contracts (2011), available at: $<$ http://www.europarl.europa.eu/document/activities/cont/201106/ 20110622ATT22311/20110622ATT22311EN.pdf>.

8 European Parliament Resolution, supra n. 4, § 1.5. See also Insol Report, supra n. 2, at pp. 16-17.

9 European Parliament Resolution, supra n. 4, Part 3. 
Additionally, it proposed to create an insolvency register in order to provide panEuropean transparency to insolvency proceedings. ${ }^{10}$

Significantly, however, the European Parliament did not propose to harmonise rules on creditors' priorities, set-off rights and termination of executing contracts. ${ }^{11}$ This is surprising since the recitals of the European Parliament Resolution consider that the current lack of harmonisation with regard to creditors' priorities 'reduces predictability of outcomes of judicial proceedings' ${ }^{12}$

Meanwhile, the European Commission has issued a new proposal to reform the Insolvency Regulation, ${ }^{13}$ which does not follow the recommendation of the European Parliament to partially harmonise insolvency law.

The purpose of this paper is to show the intrinsic difficulty faced by the European institutions in harmonising creditors' priorities, set-off rights and the rules on termination of contracts. These 'distributional rules' affect the equal treatment of creditors in the distribution of a debtor's assets and are a politically highly sensitive matter as they embody a specific balance of values and interests. Reform of distributional rules therefore requires a high level of political legitimacy and consensus.

The paper is structured as follows. The next section deals with the differences between distributional rules across jurisdictions. In the third section, I discuss two problematic issues of today's EU insolvency law. On the one hand, the Insolvency Regulation provides for a number of exceptions to the universal application of the law of the COMI, revealing Member States' desire to govern insolvencies affecting local interests. On the other hand, despite the Insolvency Regulation's effort to avoid it, forum shopping has become increasingly feasible. In the fourth section, I address two alternative policy options to reform the Insolvency Regulation: to adopt a pure choice model, or to entirely harmonise insolvency rules, including distributional rules. Since distributional insolvency rules complement social security mechanisms and reflect social balances within a certain jurisdiction, both a pure choice model and full harmonisation raise legitimacy concerns.

\section{Goals of insolvency law}

After a company becomes insolvent, the relations among its stakeholders change dramatically: shareholders and creditors shift their respective economic positions

10 Ibid., Part 4.

11 The Insol Report proposed harmonising these issues as well: Insol Report, supra n. 2, at pp. 14-22.

12 European Parliament Resolution, supra n. 4, Whereas A and B.

13 European Commission, Proposal for a Regulation of the European Parliament and of the Council amending Council Regulation (EC) No 1346/2000 on insolvency proceedings, 12 December 2012, COM (2012) 744 final, 2012/0360 (COD). 
and the latter become the residual claimants of corporate activities. ${ }^{14}$ In this situation, insolvency law displaces general creditors' remedies and governs the liquidation or the workout proceedings.

The first goal of insolvency law is to limit collective action problems faced by creditors. ${ }^{15}$ Creditors cannot coordinate themselves and therefore rationally collect their debts individually and seize a debtor's assets as soon as financial distress becomes apparent. From an ex ante viewpoint, this 'race to grab' a debtor's assets is perfectly rational for individual creditors, yet, from an ex post viewpoint, it leads to inefficient outcomes for the creditors as a group if the going concern value of their debtor's assets is higher than the sum of those assets' individual market prices. In these cases, it is in the best interest of creditors to facilitate a restructuring of the corporation, to approve workout plans or to sell debtor's assets in an orderly manner so as to maximise their value. In order to address this 'common pool problem', insolvency law rules provide for a stay of individual creditors' claims during the insolvency proceedings ${ }^{16}$ and rank all unsecured creditors equally between themselves ( pari passu or par condicio creditorum). ${ }^{17}$ Additionally, individual creditors may reject workout or restructuring plans that would maintain the going concern value of the firm and would be value-enhancing for the creditors as a group, simply because they hope to be paid in full if the plan succeeds and all other creditors adhere to it ('hold-out' problem). ${ }^{18}$ To address this problem, insolvency regulations require a creditors' majority vote to approve recovery plans that will also be binding on dissenting creditors. ${ }^{19}$

The ability to address creditors' coordination problems to efficiently allocate the debtors' assets is certainly one of the cornerstones of insolvency law. However, 'real' insolvency laws across jurisdictions pursue additional goals as they also redistribute assets among creditors, departing from the pure equality rule. ${ }^{20}$ This is one of the primary reasons why insolvency laws diverge significantly from state to state. For instance, in many jurisdictions, creditors' equality suffers exceptions

14 See John Armour, Gerard Hertig and Hideki Kanda, 'Transactions with Creditors', in Reinier Kraakman, John Armour, Paul Davies, Luca Enriques, Henry Hansmann, Gerard Hertig, Klaus Hopt, Hideki Kanda and Edward Rock, eds., The Anatomy of Corporate Law, 2nd edition (Oxford, Oxford University Press 2009), at pp. 121-122.

15 Thomas H. Jackson, The Logic and Limits of Bankruptcy Law (Cambridge MA, Harvard University Press 1986), at pp. 21-25.

16 See Jay L. Westbrook, Charles D. Booth, Christoph G. Paulus and Harry Rajak, A Global View of Business Insolvency Systems (Washington D.C., The World Bank 2010), at pp. 69-73, setting out some exceptions to the general stay in different jurisdictions.

17 See Roy Goode, Principles of Corporate Insolvency Law (London, Sweet \& Maxwell 2011), at pp. 235-240.

18 Mark J. Roe, 'The Voting Prohibition in Bond Workouts', 97 Yale Law Journal (1987) p. 232.

19 Westbrook, Booth, Paulus and Rajak, supra n. 16, at p. 156.

20 Y. Rotem, 'Pursuing Preservation of Pre-bankruptcy Entitlements: Corporate Bankruptcy Law's Self-executing Mechanisms', 5 Berkeley Business Law Journal (2008), at p. 84. 
aimed at protecting specific classes of creditors, such as a debtor's family, employees, creditors having a set-off right, ${ }^{21}$ or the counterparties of specific contracts. Another clear example is claw-back actions: insolvency laws usually nullify transfers made by the debtor before its default which favour some creditors over others ('preference transfers') and transfers made at under-price ('fraudulent transfers'), ${ }^{22}$ yet the prerequisites of such avoidance, in particular the relevant timeframe and the relevance of subjective debtors' motivation, are different from state to state and are usually a highly controversial issue. These rules affect the distribution of a debtor's assets among creditors and reflect different policy goals pursued by governments and policy makers. ${ }^{23}$

\subsection{Creditors' priorities and the redistributive function of insolvency law}

Pre-insolvency bargains and entitlements between a debtor and its creditors are generally respected, so that secured creditors enjoy priority over unsecured ones. The economic reason behind pre-insolvency entitlement protection is that secured creditors' priorities limit borrowers' moral hazard and, as a consequence, expand the availability of credit and reduce its cost. ${ }^{24}$ However, the very regulation of secured credits might diverge across jurisdictions regarding the ranking of secured lenders in relation to other creditors: some insolvency laws curb the original creditors' entitlements by reducing secured creditors' priorities, carving out or exempting portions of assets realisation, or limiting self-enforcement of the security. ${ }^{25}$

More commonly, insolvency laws rank unsecured credits unequally by granting certain creditors specific 'privileges' or priorities over other unsecured creditors. In this way, insolvency regulation alters ex post the balance between stakeholders as compared to their original positions, with the aim of protecting certain classes of creditors in case of a company's default. A classic example of unsecured creditors'

21 For a summary of some carve-outs regarding the general stay of creditors' claims, see Insol Report, supra n. 2, at p. 12. On the relevance of insolvency rules to state policies, see Paul J. Omar, European Insolvency Law (Farnham, Ashgate Publishing 2004), at pp. 6-9.

22 At the same time, certain transfers that are made by a firm in financial distress, with the aim to continue its operations, are often excluded from avoidance, otherwise the firm would have no chance of recovery.

23 See Elizabeth Warren, 'Bankruptcy Policy', 54 University of Chicago Law Review (1987) p. 775; José Garrido, 'The Distributional Question in Insolvency: Comparative Aspects', 4 International Insolvency Review (1995) p. 27; John Armour, 'The Law and Economics of Corporate Insolvency: An Overview', Centre for Business Research, Working Paper No 197 (2001), at p. 8; Goode, supra n. 17, at pp. 72-79.

24 Gerard McCormack, Secured Credit and the Harmonisation of Law (Edward Elgar 2011), at pp. 55-57.

25 Rotem, supra n. 20, at p. 84; Westbrook, Booth, Paulus and Rajak, supra n. 16, at pp. 1621. 
priorities is employees' claim for due wages and social contributions. These claims often enjoy priority over those of other creditors, although the extent and ranking of such priority vary between jurisdictions. ${ }^{26}$ Another example is Member State claims for due taxes: in some jurisdictions, such claims enjoy priority over unsecured credits or even super-priority over all creditors. ${ }^{27}$

In general, a tension emerges between the interests of prioritised creditors and those of other creditors, both secured and unsecured. Insolvency rules prioritising certain classes of creditors damage other unsecured creditors, who risk not recovering anything from a debtor's estate after secured creditors and prioritised ones have been paid. ${ }^{28}$ Although the strategy to protect certain classes of creditors via insolvency rules is often understandable socially and politically, it also produces significant drawbacks, as this task is partially put on other creditors' shoulders. Each jurisdiction decides whether and how to curb pre-insolvency entitlements in order to protect certain stakeholders through specific priorities or privileges. ${ }^{29}$ This is a politically relevant decision that reflects a hierarchy of interests within a specific jurisdiction. ${ }^{30}$

Specific classes of creditors can also be protected through tax-paid social security mechanisms or through mandatory insurances, instead of via insolvency law. The equilibrium between distributive insolvency law rules and other social security strategies varies between states and is also a politically relevant decision. For instance, insolvency laws that do not redistribute value among creditors might be compensated by strong social security mechanisms. ${ }^{31}$ By contrast, redistributive insolvency rules might counterbalance weaknesses of social security institutions or, alternatively, reinforce the impact of strong social security mechanisms. ${ }^{32}$

26 Jay Westbrook, 'Universal Priorities', 33 Texas International Law Journal (1998) p. 27, at p. 30; John A. Pottow, 'Greed and Pride in International Bankruptcy: The Problems of and Proposed Solutions to "Local Interests", 10 Michigan Law Review (2006) p. 1899, at p. 1903; Paul Omar, 'The Challenge of Diverse Priority Rules in European Insolvency Laws', Eurofenix, Autumn 2011, p. 32. For an overview, see Westbrook, Booth, Paulus and Rajak, supra n, 16, at pp. 184-195. Few jurisdictions, however, prioritise employees' claims over secured creditors. In the European Union, employees' claims for due wages have priority (at least in part) even over secured credits under French law (Article L.625-8 Code de commerce) and Greek law (Statute 3588/2007, Article 154 et seq.).

27 See Andreas Piekenbrock, 'Insolvenzprivilegien im deutschen, ausländischen und europäischen Recht', 122 Zeitschrift für Zivilprozess (2009), at pp. 75-76.

28 Garrido, supra n. 23, at p. 32; Goode, supra n. 17, at p. 250.

29 See Westbrook, Booth, Paulus and Rajak, supra n. 16, at p. 188-189.

30 Garrido, supra n. 23, at p. 34, and José Garrido, 'No Two Snowflakes the Same: The Distributional Question in International Bankruptcies', 46 Texas International Law Journal (2011), at p. 474.

31 For example, in Germany, employees are paid together with common creditors and are fully compensated by a social fund financed by the employers (Insolvenzgeld: Drittes Sozialgesetzbuch $\S 3(4) ; \S \S 165$ et seq.; $\S \S 323$ et seq.).

32 This seems to be the case in France, where workers' super-priority is coupled with strong social security protection. For an overview of theories of institutional complementarities, see John 
Distributional insolvency rules, however, are not always equivalent to efficient welfare state and social security mechanisms. In this respect, the UNCITRAL Legislative Guide to cross-border insolvencies stressed that

[s]ome priorities are based on social concerns that may be addressed more readily by law other than the insolvency law, such as social welfare legislation, than by designing an insolvency law to achieve social objectives that are only indirectly related to questions of debt and insolvency. Providing a priority in the insolvency law may at best afford an incomplete and inadequate remedy for the social problem, while at the same time rendering insolvency proceedings less effective. ${ }^{33}$

This is made clear by considering employees' protection in the EU. Pursuant to the Directive on Employees Protection, Member States must create institutions that guarantee the payment of employees' outstanding claims in case of an employer's default, unless 'other forms of guarantee' offer the employees 'a degree of protection equivalent to that resulting from' the Directive. ${ }^{34}$ In this regard, it is highly debated whether insolvency priorities offer that degree of protection. A good example of this doubtful equivalence is provided by claims of merchant seamen for payment of due wages. In the UK, their protection is exclusively based on the maritime liens arising from the International Convention on Maritime Liens and Mortgages, ${ }^{35}$ which prioritise seamen's claims over those of both secured and unsecured creditors; nonetheless, the European Commission has held that such a lien 'may not always offer a degree of protection equivalent to that of the' UK National Insurance Fund, which does not apply to seamen. ${ }^{36}$

Campbell, 'The US Financial Crisis: Lessons for Theories of Institutional Complementarity', 9 Socio-Economic Review (2011) p. 211.

33 UNCITRAL Legislative Guide on Insolvency Law, at p. 271 (2005).

34 Article 1(2) Directive 2008/94/EC of 22 October 2008 on the protection of employees in the event of the insolvency of their employer (hereinafter, 'Directive on Employees Protection'), which codifies Council Directive 80/987/EEC of 20 October 1980 on the approximation of the laws of the Member States relating to the protection of employees in the event of insolvency of their employer as amended by Directive 2002/74/EC of the European Parliament and the Council of 23 September 2002. See also Article 8 of the ILO Convention on the Protection of Workers' Claims, 1992 (of the EU Member States, only Austria, Bulgaria, Finland, Latvia, Lithuania, Slovakia, Slovenia and Spain ratified this Convention): 'National laws or regulations shall give workers' claims a higher rank of privilege than most other privileged claims, and in particular those of the State and the social security system. However, where workers' claims are protected by a guarantee institution [...], the claims so protected may be given a lower rank of privilege than those of the State and the social security system.'

35 International Convention on Maritime Liens and Mortgages, 1993, Article 3.

36 Report from the Commission to the European Parliament and the Council on the implementation and application of certain provisions of Directive 2008/94/EC on the protection of employees in the event of the insolvency of their employer, 28.2.2011, COM (2011) 84 final, at p. 3. 
In order to understand its effects, insolvency law cannot be separated from the web of social and legal relations in which it is embedded. As we have seen above, an absolute priority for secured creditors ex ante increases the amount of credit and reduces its cost. This strategy, however, conflicts with other interests, such as those of employees and small creditors, and might impede a debtor's recovery or disincentivise firm-specific commitments of workers and commercial partners. ${ }^{37}$ In turn, legislation that prioritises unsecured credits over secured ones also comes at a social cost, since it can increase the cost of credit or discourage banks to concede loans. In other words, a trade-off exists between different policy goals and interests; policy makers strike a balance between such interests and goals according to their own policy options and strategies. This explains some of the differences between insolvency laws across countries, which also derive from different economic needs, voters' heterogeneous preferences and corresponding political decisions.

\subsection{Political economy of insolvency law}

As a result of the redistributive impact of insolvency rules, different groups of creditors and stakeholders ${ }^{38}$ have diverging views as to the proper purposes of insolvency proceedings. ${ }^{39}$ To be sure, all interest groups are likely to share some common goals, namely that the competent court and the insolvency trustee or liquidator act fast and efficiently, and that insolvency law addresses coordination problems among creditors. However, the interests of sophisticated creditors, such as banks and financial institutions (hereinafter 'adjusting creditors'), usually diverge from those of non-sophisticated ones (hereinafter 'non-adjusting creditors') in regard to other issues.

Adjusting creditors can take the risk of a debtors' default into account in the interest rates or can require securities, such as a lien, a pledge or a contractual covenant. Consequently, they advocate insolvency legislations that respect preinsolvency entitlements and allow them to enforce their debts during insolvency proceedings. Regarding the avoidance of fraudulent and preference transfers, adjusting creditors, having a strong influence on debtors' pre-insolvency behaviour, prefer rules that restrict avoidance, in order to limit the risk that courts nullify payments made and guarantees granted before the insolvency.

${ }^{37}$ Lucian A. Bebchuk and Jesse M. Fried, 'The Uneasy Case for the Priority of Secured Claims in Bankruptcy', 105 Yale Law Journal (1996), at pp. 885-887.

38 Besides creditors, we should also mention the position of managers who lobby for legislation that does not displace them during the insolvency and that limits their risk of liability and derivative actions for mismanagement or wrongful trading. See Barry E. Adler, 'Financial and Political Theories of American Corporate Bankruptcy', 45 Stanford Law Review (1992-1993), at pp. 343-344.

39 Troy A. McKenzie, 'Judicial Independence, Autonomy, and the Bankruptcy Courts', 62 Stanford Law Review (2010), at pp. 774-775. 
By contrast, non-adjusting creditors, ${ }^{40}$ who do not have a similar bargaining position, advocate legislation that curbs pre-insolvency entitlements to their advantage, limits secured creditors' priorities and rights, and increases avoidance of payments made in the vicinity of insolvency. ${ }^{41}$ Among non-adjusting creditors, it is useful to distinguish employees, who are integrated into the business together with other productive factors. Employees are likely to make firm-specific investments, so that their risk is highly undiversified and job losses affect them and their families more than commercial creditors. ${ }^{42}$ Therefore, employees advocate insolvency legislations that grant them priority for all due wages, that do not interrupt the employment contract and that favour a restructuring of the firm.

These conflicts of interests become even more prominent if the defaulted company has assets, creditors or suppliers in many jurisdictions. Each of these states has a political interest in regulating the insolvency, even if the debtor is incorporated elsewhere. We can imagine the case of a company incorporated in country A and having all its assets, activities and creditors in country B. In this situation, country B is more affected than country A by this firm's default and, additionally, the courts or insolvency trustee of country A will face significant obstacles in seizing assets located in country B.

In this scenario, different interest groups are likely to sponsor diverging solutions as to the applicable insolvency law and the reach of courts' powers. Nonadjusting creditors and employees have a strong interest in insolvencies being governed by domestic courts and rules, which they can influence through democratically elected representatives. Adjusting creditors, by contrast, can protect themselves with an adequate contractual covenant or securities, or can take the risk of default and the risks associated with the applicable insolvency law into account in the price of credit. Consequently, their primary interest is to predict which court will be competent and what will be the applicable law in case of a debtor's default. ${ }^{43}$ Additionally, they will sponsor any solution that allows maintaining the validity of pre-insolvency securities.

40 However, things might be more complicated whenever some non-adjusting creditors are able to pool classes of debtors together and apply to them the same interest rate or the same price ('weak non-adjusting creditors'): Andrew T. Guzman, 'International Bankruptcy: In Defense of Universalism', 98 Michigan Law Review (1999-2000) p. 2177.

41 Bebchuk and Fried, supra n. 37, at pp. 882-887: legislations that respect pre-insolvency bargains and proprietary guarantees distribute value among creditors to the advantage of secured creditors.

42 Goode, supra n. 17, at p. 250.

43 Miguel Virgos and Etienne Schmit, Report on the Convention on Insolvency Proceedings, Council of the European Union, Doc. 6500/96/EN (1996), para. 75: 'Insolvency is a foreseeable risk. It is therefore important that international jurisdiction [...] be based on a place known by the debtor's potential creditors.' See also Horst Eidenmüller, 'Der Markt für internationale Konzerninsolvenzen: Zuständigkeitskonflikte unter der EuInsVO', Neue Juristische Wochenschrift (2004), at p. 3456, and idem, 'Free Choice in International Company Insolvency Law', 6 European Business Organization Law Review (2005), at p. 429; Bob Wessels, Current Topics on International Insolvency Law (Kluwer 2004), at p. 160. 


\section{INSOLVENCY LAW IN THE EU: FROM THE GOAL TO AVOID FORUM SHOPPING TO A CHAOTIC CHOICE MODEL}

As reported in the first section, Member States where debtors have their COMI are competent to govern their main insolvency proceedings, and the law of the state of the COMI applies to all of a debtor's assets and creditors, regardless of their location. ${ }^{44}$ In particular, the state of the COMI is competent not only to govern the insolvency proceedings, but also to regulate distribution criteria. ${ }^{45}$ The Insolvency Regulation specifies that the COMI is in the place where the debtor "conducts the administration of his interests on a regular basis and is therefore ascertainable by third parties' ${ }^{46}$ Consequently, a debtor's COMI is likely to be in the Member State where most of its stakeholders are located and which is therefore the most interested in governing a debtor's insolvency. These rules were meant to form a wellordered system granting clarity and legal certainty. A closer look, however, reveals that the application of the Insolvency Regulation is quite different from its original official goals. On the one hand, the Regulation provides for numerous exceptions to the law of the COMI in order to deal with the interests of other Member States in regulating specific 'local' issues. On the other hand, the evolution of EU case law on companies' freedom of establishment and the Cross-Border Merger Directive of 2005 have allowed different forms of forum shopping to creep in.

\subsection{Exceptions to the powers of the state of the COMI}

Despite the fact that the Insolvency Regulation follows the universality principle, the regulatory powers of the state of the COMI suffer a number of carve-outs and

44 On the principle of universality, see Jay Lawrence Westbrook, 'Theory and Pragmatism in Global Insolvencies: Choice of Law and Choice of Forum', 65 American Bankruptcy Law Journal (1991) p. 457; Lucian A. Bebchuk and Andrew T. Guzman, 'An Economic Analysis of Transnational Bankruptcies', 42 Journal of Law and Economics (1999) p. 775; Guzman, supra n. 40.

45 Article 4(2) Insolvency Regulation. Additionally, all actions deriving from an insolvency, such as board liabilities for delaying the filing for insolvency and wrongful trading, should be governed by courts of the state of the COMI: European Court of Justice, C-133/78 Gourdain v. Nadler [1979] R-I 733 (on the French action en comblement du passif); European Court of Justice, C-330/07, Frick Teppichboden Supermärkte GmbH v. Deko Marty Belgium B [2009] ECR I-767 (the courts of the State of the COMI are competent in respect of avoidance actions); European Court of Justice, C-444/07 MG Probud Gdnia sp. z. o.o. [2010]. See Alexander Schall, 'The UK Limited Company Abroad - How Foreign Creditors Are Protected After Inspire Art', 16 European Business Law Review (2005) p. 1553; Luca Enriques and Martin Gelter, 'Regulatory Competition in European Corporate Law and Creditor Protection', 7 European Business Organization Law Review (2006), at p. 440. We must be aware, however, that characterisation differences can still arise across the EU: Stefania Bariatti, 'Filling the Gaps of EC Conflicts of Laws Instruments: The Case of Jurisdiction over Actions Related to Insolvency Proceedings', Liber F. Pocar (Milan, Giuffrè 2009) p. 23.

46 Recital 13 Insolvency Regulation. 
exceptions that favour Member States where certain assets, stakeholders or activities are located. The underlying logic is that another Member State is 'closer' to the interests involved (or to some of them) than the state of the COMI. Politically, these carve-outs signal that Member States are reluctant to entirely defer to others the regulation of specific issues or of proceedings having a significant 'local' impact.

The first and most significant exception to the competence of the state of the COMI is the power granted to Member States where the debtor has an 'establishment' to open secondary proceedings with territorial effects and liquidation purposes. ${ }^{47}$ Secondary proceedings exclusively follow the insolvency rules and creditors' priorities of such a Member State. ${ }^{48}$ This mechanism, usually labelled as 'modified universalism', is a pragmatic solution to the main obstacle in the way of full acceptance of universalism, namely the different creditors' priorities across jurisdictions. ${ }^{49}$ This compromise, however, is also, per se, a significant breach in the logic of the universality principle ${ }^{50}$ and a big concession to the 'territoriality' idea, ${ }^{51}$ according to which the state where a debtor's assets are located should sbe competent to govern their liquidation and distribution to creditors. ${ }^{52}$ Indeed, after the opening of secondary proceedings, assets located in the Member States where these proceedings have been commenced are not available under the main proceedings and are to be distributed according to creditors' priorities set by the Member State of establishment..$^{53}$ The very opening of secondary proceedings may therefore disrupt the effectiveness of the main proceedings.

Major flexibility would be achieved if the courts of the main proceedings could apply the distributive rules of the state of establishment to assets and creditors

47 Article 2 Insolvency Regulation. See Gerard McCormack, 'Jurisdictional Competition and Forum Shopping in Insolvency Proceedings', 68 Cambridge Law Journal (2009), at pp. 174-175.

48 Article 28 Insolvency Regulation.

49 Garrido, supra n. 30, at p. 470.

50 See Ian F. Fletcher, Insolvency in Private International Law (London, OUP 2005), at p. 371; Sefa M. Franken, 'Three Principles of Transnational Corporate Bankruptcy Law: A Review', 11 European Law Journal (2005), at p. 235.

${ }^{51}$ Frederick Tung, 'Is International Bankruptcy Possible?', 23 Michigan Journal of International Law (2001), at p. 77.

52 In support of the territoriality principle, see Lynn M. LoPucki, 'Cooperation in International Bankruptcy: A Post-Universalist Approach', 84 Cornell Law Review (1998-1999), at p. 722, and idem, Courting Failure (Ann Arbor, University of Michigan Press 2005), at p. 209.

53 The opening of secondary proceedings can be used to contrast the implementation of main proceedings. See, for example, the insolvency of the Illochroma group: Illochroma Italia s.r.l. was an Italian company incorporated in Ivrea and belonging to the insolvent French Illochroma group. The Tribunal of Commerce of Roubaix stated that the COMI of Illochroma Italia s.r.l. was located in France, although all its assets, plants and commercial activities were in Italy. As a reaction, the Tribunal of Ivrea decided to open secondary proceedings against the same company: Corte d'Appello Torino, 10/3/2009, Il Fallimento (11/2009), at p. 1296. 
located there. This solution was adopted in the British Collins \& Aikman case, ${ }^{54}$ where the administrator of a holding company having subsidiaries in other Member States committed himself with local creditors of such states to respecting their distributive rules and to partially disregarding UK priorities. Courts of other Member States, however, do not enjoy a similar degree of flexibility. The recent proposal of the European Commission to reform the Insolvency Regulation explicitly codifies the rule in Collins \& Aikman as it enables liquidators to commit themselves to respecting 'distribution and priority rights which local creditors would have had if secondary proceedings had been opened'. ${ }^{55}$ This solution is flexible and pragmatic but is a further limitation of the universality principle, underlining how Member States are still protecting their own creditors' priorities.

Furthermore, the Insolvency Regulation provides for a number of carve-outs, which limit the exclusive power of the state of the COMI to set the rules on creditors' equality. ${ }^{56}$ In most cases, the competence of the state of the COMI is excluded with regard to a debtor's assets located in the territory of another Member State. This is the case for rights in rem over a debtor's assets, ${ }^{57}$ reservation of title, ${ }^{58}$ contracts related to immovable properties, ${ }^{59}$ rights subject to registration (regarding which the law of the state of the register prevails $)^{60}$ and third parties' purchase of certain kinds of assets. ${ }^{61}$ Some of these carve-outs are aimed at respecting preinsolvency entitlements and displace the power of the state of the COMI to modify them. For instance, rights in rem, ${ }^{62}$ such as a pledge or other securities, over a debtor's assets situated in a Member State different from the state of the COMI cannot be disregarded by the competent court. ${ }^{63}$ Following this rule, securities qualified as right in rem over a moveable asset, such as a pledge, or over a collection of assets, such as floating charges, are to be respected in the insolvency pro-

54 Re Collins \& Aikman Europe SA [2006] EWHC 1343 (Ch). See Gabriel Moss, 'Group Insolvency - Choice of Forum and Law: The European Experience Under the Influence of English Pragmatism', 32 Brooklyn Journal of International Law (2008), at pp. 1017-1018.

55 Reform Proposal, supra n. 13, Article 28(a), amending Article 18(1) of the Insolvency Regulation.

56 McCormack, supra n. 47, at p. 175.

57 Article 5 Insolvency Regulation.

58 Article 7 Insolvency Regulation.

59 Article 8 Insolvency Regulation.

60 Article 11 Insolvency Regulation.

61 Article 14 Insolvency Regulation.

62 On the characterisation as 'rights in rem', see Michael Veder, Cross-border Insolvency Proceedings and Security Rights (Kluwer 2004), at pp. 332-336 (who makes a case for independent interpretation); Fletcher, supra n. 50, at p. 406 (autonomous characterisation by each Member State); Omar, supra n. 21, at pp. 161-164.

63 Article 5 Insolvency Regulation, which, however, does not set a conflicts rule and does not establish which law is to be applied: Goode, supra n. 17, at p. 768; Christoph Paulus, Europäische Insolvenzverordnung. Kommentar, 4th edn. (Frankfurt a.M., Verlag Recht und Wirtschaft 2010), at p. 164. 
ceedings if the assets are located in another Member State, with the consequence that creditors' priorities established by the state of the COMI do not apply. ${ }^{64}$

The conflict of law criterion to be applied to claw-backs of pre-insolvency transactions is even more significant. As we have seen above, the general principle is that the law of the COMI also regulates avoidance actions, ${ }^{65}$ yet transactions subject to the law of another Member State remain valid if such law 'does not allow any means of challenging the act in the relevant case' ${ }^{66}$ The rationale is protection of trust, under the premise that contractual parties rely on the application of avoidance rules of the law regulating the contract. In practice, however, this rule favours adjusting creditors that can impose the application to lending contracts of a law that restricts avoidance. ${ }^{67}$

To be sure, not all exceptions to the law of the COMI aim at protecting sophisticated creditors. Significantly, the law governing employment contracts regulates the effects of insolvency proceedings on such contracts as well. This carve-out applies exclusively to contractual issues, such as whether and under what circumstances the insolvency trustee must continue the employment contract or can terminate it. ${ }^{68}$ By contrast, the state of the COMI governs creditors' ranking, including employees' priorities, regardless of the law applicable to the contract, while the law of the state where the employees carry out their work is competent to regulate any payment of social securities or state guarantees for unpaid due wages. ${ }^{69}$

\subsection{Corporate mobility and regulatory arbitrage regarding insolvency law}

One of the goals of the Insolvency Regulation is to avoid forum shopping and regulatory arbitrage..$^{70}$ In order to pursue this goal, the Insolvency Regulation relied upon two implicit premises: that European corporations did not significantly expand their activities outside their home country, so that their COMI could be easily determined, and that companies could not 'reincorporate' from one Member State to another without liquidating. These premises are no longer realistic due to the evolution of European economic integration and of EU law on freedom of establishment.

Indeed, European corporations have increasingly extended their activities throughout the whole territory of the European Union. This fact is to be celebrated as a success of market integration policies, aimed at achieving a single internal

\footnotetext{
64 Veder, supra n. 62, at p. 342.

65 Article 4(2)(m) Insolvency Regulation.

66 Article 13 Insolvency Regulation.

67 See Insol Report, supra n. 2, at p. 19.

68 See Bob Wessels, International Insolvency Law (Kluwer 2012), at pp. 621-622.

69 Article 9(1) Directive on Employees Protection.

70 Recital 4 Insolvency Regulation.
} 
market in the EU. At the same time, the continental extension of the activities of European companies increases uncertainties as to the location of their COMIs due to the fuzziness of this standard. ${ }^{71}$ To be sure, in order to simplify its determination, a company's COMI is presumed to be in the Member State of the registered office, unless the contrary is proven. ${ }^{72}$ The goal of this rule is to increase predictability ex ante, since creditors need to know which law will be applied in case of insolvency so that they can take the 'value' of that law into account in the price of credit. The presumption that the COMI coincides with the registered office, however, only provides legal predictability if divergences between the registered office and the 'real' COMI are rare ${ }^{73}$ and if cross-border mobility of the registered office is impossible or extremely difficult. Both premises are no longer realistic on account of the evolution of EU law and to ECJ case law.

Due to the ECJ's decisions after the Centros case in 1999, a company's headquarters can be located in a Member State different from the state of incorporation (provided that the latter accepts this dissociation). ${ }^{74}$ Therefore, companies can conduct their business entirely from a Member State different from the state of incorporation. ${ }^{75}$ In these cases, the company's COMI is in the Member State where the headquarters is, provided that this is ascertainable by third parties; however, the

71 Franken, supra n. 50, at pp. 251-254; Massimo Benedettelli, “ “Centro degli interessi principali" del debitore e forum shopping nella disciplina comunitaria delle procedure di insolvenza transfrontaliera', Rivista italiana di diritto internazionale privato e processuale (2004), at pp. 525-528 (stressing that, despite the wording in Recital 4 of the Insolvency Regulation, the COMI criterion already allows forum shopping); Christoph Paulus, 'Global Insolvency Law and the Role of Multinational Institutions', 32 Brooklyn Journal of International Law (2007), at p. 764; Gerard McCormack, 'Reconstructing European Insolvency Law - Putting in Place a New Paradigm', 30 Legal Studies (2010), at pp. 129-133.

72 Article 3 Insolvency Regulation. As a result, if this presumption is not rebutted, the same state will be competent for both corporate and insolvency rules, which is consistent with the strong correlations between these sets of rules. See John Armour, "Who Should Make Corporate Law: EC Legislation Versus Regulatory Competition', 58 Current Legal Problems (2005), at pp. 401-403, and Christoph Paulus, 'Konturen eines modernen Insolvenzrechts - Überlappungen mit dem Gesellschaftsrecht', 61 Der Betrieb (2008) p. 2523.

${ }^{73}$ See Virgos-Schmit Report, para. 75, supra n. 43: 'the registered office normally corresponds to the debtor's head office'.

74 European Court of Justice, C-212/97, Centros Ltd v. Erhvervsog Selskabsstyrelsen [1999] ECR I-1459; European Court of Justice, C-208/00, Überseering BV v. Nordic Construction Company Baumanagement GmbH [2002] ECR I-9919; European Court of Justice, C-167/01, Kamer van Koophandel en Fabrieken voor Amsterdam v. Inspire Art, [2003] ECR I-1095.

75 Eidenmüller, 'Free Choice', supra n. 43, at p. 430; Gabriel Moss and Christoph Paulus, 'The European Insolvency Regulation - The Case for Urgent Reform', 19 Insolvency Intelligence (2006), at p. 3; McCormack, supra n. 47, at p. 191. On the impact of corporate mobility on the applicable insolvency law, see also Sebastian Mock, 'Gläubigerschutz in der Europäischen privatgesellschaft zwischen Gesellschafts- und Insolvenzrecht,' Der Konzern (2008), at pp. 542544; Mathias M. Siems, Leif Herzog and Erik Rosenhäger, 'The Protection of Creditors of a European Private Company’, 12 European Business Organization Law Review (2011) p. 147. 
presumption that a corporation's COMI coincides with its registered office points in the opposite direction, and the burden to overcome such presumption might be considerable. Additionally, conflicts of jurisdiction are governed by the "priority principle', according to which '[a]ny judgment opening insolvency proceedings handed down by a court of a Member State which has jurisdiction pursuant to Article 3 shall be recognised in all the other Member States'; ${ }^{76}$ therefore, if a court of the state of incorporation opens insolvency proceedings, courts of other states can only open secondary territorial proceedings, since there is no effective and binding legal mechanism to challenge the decision of the first court.

On top of that, reincorporations throughout the EU have become feasible in the last years, despite the lack of a specific directive. ${ }^{77}$ The main reason is that, in 2005 , a Directive was enacted regulating cross-border mergers: these are now viable, though costly and time-consuming, mechanisms to transfer the registered office from one Member State to another by incorporating a shell company and then merging into it. ${ }^{78}$ Eventually, a decision of the ECJ has declared that freedom of establishment grants companies the right to reincorporate from one Member State to another, yet this statement was probably obiter dictum. ${ }^{79}$ At the moment, although some Member States, such as the UK and Germany, ${ }^{80}$ still do not allow

76 Article 16 Insolvency Regulation. On the effects of the priority principle, see Thomas Bachner, 'The Battle over Jurisdiction in European Insolvency Law', 7 European Company and Financial Law Review (2006), at p. 318, and Luca Enriques and Martin Gelter, 'How the Old World Encountered the New One: Regulatory Competition and Cooperation in European Corporate and Bankruptcy Law', 81 Tulane Law Review (2007), at pp. 635-637.

77 The Proposal for a Directive on the cross-border transfer of registered office was eventually dismissed: Impact Assessment on the Directive on the Cross-border Transfer of Registered Office, Brussels, 12.12.2007 SEC (2007) 1707. See, however, European Parliament Resolution of 2 February 2012 with recommendations to the Commission on a 14th Company Law Directive on the cross-border transfer of company seats (2011/2046(INI)), and the Report of the Reflection Group on the Future of EU Company Law, 5 April 2011, at pp. 17-20, available at: $<$ http://ec. europa.eu/internal_market/company/docs/modern/reflectiongroup_report_en.pdf $>$.

78 If the country of arrival follows the real seat theory, the emigrating company also needs to transfer its headquarters; by contrast, if the country of arrival does not require domestically incorporated companies to also have their headquarters in the same territory, foreign companies can simply reincorporate there without transferring any physical assets or the headquarters.

79 European Court of Justice, C-210/06, CARTESIO Oktató és Szolgáltató [2008] ECR I09641. See António Frada de Sousa, 'Company's Cross-border Transfer of Seat in the EU After Cartesio', NYU Jean Monnet Working Paper 07/09, and Andrzej W. Wiśniewski and Adam Opalski, 'Companies' Freedom of Establishment After the ECJ Cartesio Judgment', 10 European Business Organization Law Review (2009) p. 595; Stefano Lombardo, 'Regulatory Competition in Company Law in the European Union After Cartesio', 10 European Business Organization Law Review (2009) p. 627.

${ }^{80}$ Legal practitioners, however, have found a way to avoid such prohibition; for an account, see Marc-Philippe Weller, 'Die Verlegung des Centre of Main Interest von Deutschland nach England', 37 Zeitschrift für das gesamte Handels- und Gesellschaftsrecht (2008), at p. 863, and 
reincorporations, many others, such as France, Spain and Italy, do. ${ }^{81}$ After reincorporating from one Member State to another, a company's COMI is presumed to be in the Member State of the new registered office. The relevant moment to determine the COMI is exclusively the filing for insolvency, even if the debtor transferred its registered office before the insolvency. ${ }^{82}$ Consequently, if a company succeeds in reincorporating in another Member State, it indirectly selects the applicable insolvency law, unless creditors provide evidence that the COMI is still in the original state.

Although the original intention of the Regulation was to avoid forum shopping, the evolution of EU law has changed the legal scenario and has converted the Insolvency Regulation into a hybrid, which, to a certain extent, allows forum shopping. It is increasingly common for corporations to dissociate their activities and headquarters from the registered office or to transfer their registered office abroad ${ }^{83}$ the result being that the presumption of coincidence between COMI and registered office does not produce the same effects as envisaged by the drafters of the Insolvency Regulation. ${ }^{84}$ However, creditors can provide convincing evidence that the COMI is still in the original country. ${ }^{85}$ In sum, the European model allows debtors to indirectly influence the choice of competent venue, yet does not grant legal certainty and predictability.

\section{THE REFORM OF THE INSOLVENCY REGULATION AND ITS POLITICAL DIMENSION}

This section addresses two opposite solutions to the reform of cross-border insolvency in the European Union: to entirely harmonise insolvency law, including rules on creditors' priorities, or to allow companies to select the insolvency law they prefer ('choice model'). Although neither has been proposed by the EU institutions in their efforts to amend the present regime, analysis of both is necessary to shed light on any future development.

Wolf-Georg Ringe, 'Forum Shopping under the EU Insolvency Regulation', 10 European Business Organization Law Review (2009), at pp. 585-586.

81 Federico M. Mucciarelli, 'The Function of Corporate Law and the Effects of Reincorporations in the U.S. and the EU', 20 Tulane Journal of International and Comparative Law (2012), at pp. 429-430.

82 European Court of Justice, C-396/09, Interedil Srl [2011] ECR I-000.

${ }^{83}$ For instance, the case discussed in the Interedil decision of the ECJ concerned a statutory seat transfer from Italy to the UK.

${ }^{84}$ See also M. Menjucq, 'EC-Regulation No 1346/2000 on Insolvency Proceedings and Groups of Companies', 5 European Company and Financial Law Review (2008), at pp. 136-137.

85 Marek Szydło, 'Prevention of Forum Shopping in European Insolvency Law', 11 European Business Organization Law Review (2010), at p. 261. 


\section{$4.1 \quad$ Choice model}

\subsubsection{The case for the choice model in the European Union}

A number of legal scholars reject harmonisation of insolvency law and suggest regulating regulatory arbitrage and forum shopping in a transparent way, instead of denying their existence (as the Insolvency Regulation now does). This solution is supported by efficiency motivations. Under a choice model, companies would not be trapped into inefficient domestic proceedings and could choose another Member States' law if they considered it more efficient than the domestic law or if such proceedings allowed a restructuring that would be impossible under the original law. ${ }^{86}$ In other words, corporations would take advantage of the legal diversity across the EU and could avoid inefficient and slow domestic regulations and proceedings. ${ }^{87}$

Indeed, some cases of successful regulatory arbitrage are reported whereby distressed corporations managed to move the registered office and the COMI to another Member State to take advantage of workout mechanisms not available under the original law; in the two most significant, and most cited, of these cases, German companies managed to convert into English ones in order to enter into a debt-equity swap and to facilitate the approval of workout plans by creditors. ${ }^{88}$

In order to implement a choice model in the EU, two alternative solutions are available. The first option is to allow free choice of insolvency law, regardless of the applicable company law ('unbundled free choice'). A different solution, however, has gained more consensus among legal scholars, namely to replace the COMI with the registered office as choice of law and choice of forum criterion. ${ }^{89}$ Consequently, newly established companies, by incorporating under the law of a certain Member State, would implicitly choose the applicable insolvency law as

86 Robert K. Rasmussen, 'A New Approach to Transnational Insolvencies', 19 Michigan Journal of International Law (1997-1998) p. 1, and idem, 'Resolving Transnational Insolvencies Through Private Ordering', 98 Michigan Law Review (1999-2000) p. 2252; Eidenmüller, 'Free Choice', supra n. 43, at p. 429; Franken, supra n. 50, at pp. 241-246; Ringe, supra n. 80, at p. 601.

87 On the efficiency of legal plurality, see Roger van den Bergh, 'Subsidiarity as an Economic Demarcation Principle and the Emergence of European Private Law', 5 Maastricht Journal of European Law (1998) p. 140.

88 See Weller, supra n. 80, at p. 863; Ringe, supra n. 80, at pp. 585-586.

89 See Armour, supra n. 72, at pp. 407-408; Eidenmüller, 'Free Choice', supra n. 43, at p. 438; Ringe, supra n. 80, at p. 615; Szydło, supra n. 85, at pp. 270-271. However, see McCormack, supra n. 71, at pp. 135-137, for whom the main problem of adopting the registered office as choice-of-law criterion is that this solution does not address groups of companies. To deal with this issue, the author suggests granting greater autonomy as to the Member States where the insolvency petition can be lodged, following the US model. Along the same lines, see also Benedettelli, supra n. 71, at p. 517, who stresses that the present Insolvency Regulation already allows beneficial forms of forum shopping. 
well. Under both versions of the choice model, insolvency law would be predictable ex ante, so that creditors can anticipate the rules in the cost of credit or in the contract. ${ }^{90}$ This solution may also contribute to reducing the cost of credit, since debtors will not choose insolvency regulations that 'systematically shift wealth from creditors to shareholders' ${ }^{91}$ Under such premises, therefore, the choice model, by allowing shareholders and directors to transparently select the preferred insolvency law, would also increase overall efficiency.

\subsubsection{Drawbacks of the choice model}

Despite these strong arguments, however, a choice model has some weaknesses, since it would not be neutral towards the interests of the stakeholders involved. To understand how free choice of insolvency law can affect creditors' interests, it is necessary to distinguish midstream changes of applicable insolvency law from the original choice made at the moment of incorporation. In the following analysis, I address a 'pure' choice model, where there is just one competent jurisdiction and no exceptions to the universality principle.

\subsubsection{Midstream changes of applicable insolvency law}

Under the choice model, companies would be allowed to change the originally applicable insolvency law by shifting their registered office to another state. As we have seen, insolvency rules have redistributive effects among corporate stakeholders and are not neutral towards creditors' interests. Therefore, by changing the applicable insolvency law, a debtor would modify its risk profile, which creditors took into account in the contractual conditions. Ex ante, adjusting creditors would protect themselves through adequate covenants or guarantees, or by raising the cost of credit.

Non-adjusting creditors, however, risk suffering from a debtor's opportunistic change of law..$^{92}$ To resolve this problem, legislations must grant existing creditors either the right to receive a guarantee, or the right to be paid in advance if their debtors change the applicable insolvency law. ${ }^{93}$ Such creditor protection mechanisms are already provided for in the Cross-Border Merger Directive, which requires Member States to implement 'provisions and formalities' for the 'protection

90 Franken, supra n. 50, at p. 245.

91 Ibid.; Ringe, supra n. 80, at p. 602-603.

92 Franken, supra n. 50, at p. 245.

93 Horst Eidenmüller, 'Abuse of Law in the Context of European Insolvency Law', 1 European Company and Financial Law Review (2009), at p. 13 (who stresses that if the COMI is transferred together with the registered office, domestic mechanisms for creditor protection apply); Franken, supra n. 50, at p. 246 (prevention of abuse of bankruptcy selection clauses might require some form of mandatory regulation). 
of creditors of the merging companies'. ${ }^{94}$ In implementing this provision, many Member States grant pre-existing creditors the right to oppose the merger or to obtain a security. In order to fully protect pre-existing non-adjusting creditors in a choice model, such creditors' protection mechanisms should be extended to crossborder transfers of registered offices as well..$^{95}$

In other words, midstream forum shopping and regulatory arbitrage raise policy issues that can be resolved through adequate legal mechanisms that protect creditors. If these safeguards are in place, potentially damaged creditors will always be rewarded, so that the efficiency gains produced by midstream changes of insolvency law outweigh their costs and there is no reason to ban such transactions. ${ }^{96}$

\subsubsection{Choice of applicable insolvency law at the moment of incorporation}

The original selection of the applicable insolvency law raises far more concerns. Due to the development of ECJ case law on freedom of establishment, companies can run their business entirely from a Member State different from the state of incorporation, if this state so allows. ${ }^{97}$ Therefore, if the registered office replaces the COMI, companies can select the preferred insolvency jurisdiction at the moment of incorporation, regardless of the location of the assets, creditors and employees. For example: the insolvency of an English Ltd whose business is exclusively in Germany would be governed by English courts and by English insolvency law and creditors' priorities.

According to a widespread view, as long as this initial choice of law is made in a transparent way, future creditors cannot be harmed because they anticipate the

94 Article 4(2) Directive 2005/56/EC of the European Parliament and of the Council, of 26 October 2005 on cross-border mergers of limited liability companies. See Mucciarelli, supra $\mathrm{n}$. 81 , at pp. $463-464$.

95 Italian law is an example of weak creditors' protection. Under Italian law, the cross-border transfer of the registered office is feasible in practice (see Articles 2437 and 473 of the Italian Civil Code), yet such transfer is not regulated and there are no explicit mechanisms for creditors' protection, which raises the risk of opportunistic forum shopping. This is demonstrated by the Interedil case decided by the ECJ, where an Italian limited liability corporation moved its seat to England and managed to 'disappear' before the opening of insolvency proceedings: European Court of Justice, C-396/09, Interedil Srl, supra n. 82; see Federico Mucciarelli, 'The Hidden Voyage of a Dying Italian Company: From the Mediterranean Sea to Albion', 9 European Company and Financial Law Review (2012) p. 571. On creditors' protection in case of reincorporation, in general, see Massimo Benedettelli, 'Libertà comunitarie di circolazione e diritto internazionale privato', Rivista italiana di diritto internazionale privato e processuale (2001) p. 615; Federico Mucciarelli, Società di capitali, trasferimento all'estero della sede sociale e arbitraggi normativi (Milan, Giuffrè 2010), at pp. 193-194.

96 Ringe, supra n. 80, at p. 607.

97 The state of incorporation can apply its own conflict of law rules and its own domestic substantial rules as to the relation between headquarters and registered office; therefore, Germany can still require domestic companies to have their headquarters in the domestic territory. 
applicable insolvency law in the contractual conditions or in the interest rate. ${ }^{98}$ Consequently, no negative externalities and inefficiencies can ever arise from the initial choice of the applicable insolvency law.

However, only adjusting creditors can take account of the applicable insolvency regime in the contractual conditions and have sufficient resources at their disposal to lodge their claims in another jurisdiction. ${ }^{99}$ By contrast, non-adjusting creditors, such as involuntary creditors, employees or small trade partners, cannot anticipate the applicable law in the contractual conditions and cannot protect themselves through diversification. Additionally, the cost of lodging their claims in another jurisdiction hinges on the price of legal services and on lawyers' fees, which diverge significantly across Member States ${ }^{100}$ and are likely to be onerous for small creditors.

The most relevant problem regarding the initial choice of insolvency law is related to priority regimes. As we have seen above, priority regimes are a highly political matter, intertwined with national social security policies, and convey a hierarchy of interests and values. Under a pure choice model, the priority regime of the Member State selected by the insolvent company would apply to all creditors throughout the European Union. The competent Member State would lay down distributive insolvency rules according to its own balance of interests and hierarchy of values, which would also affect other Member States' local constituencies. It is realistic to argue that adjusting creditors would press their debtors or potential debtors into selecting an insolvency regime that grants them unrestricted priority rights, even if the proceedings are inefficient or do not facilitate a debtor's recovery. ${ }^{101}$ If companies could only select the insolvency law together with the applicable company law, sophisticated lenders would induce the founders of newly established companies to incorporate in Member States that 'over-prioritise' their claims, while non-adjusting creditors located in other Member States would be at the mercy of this initial choice. This is a typical 'spillover effect' that risks generating negative externalities and resources misallocation. ${ }^{102}$ On top of that, this outcome raises legitimacy concerns and would face significant political opposition.

98 Franken, supra n. 50, at p. 245.

99 See Enriques and Gelter, supra n. 45, at pp. 432-433, as regards reincorporations abroad.

100 See Study on the Transparency of Costs of Civil Judicial Proceedings in the European Union, implemented by Demolin, Brulard, Barthelemy for the European Commission, available at: $<$ https://e-justice.europa.eu/content_costs_of_proceedings-37-eu-en.do $>$ (last visited 9 December 2012).

101 Eidenmüller, 'Free Choice', supra n. 43, at p. 437 (only with regard to free choice of insolvency forum separated from the applicable company law).

102 A certain regulation or a certain allocation of goods is efficient in an intra-jurisdictional sense when it minimises the costs paid by the constituencies of a specific jurisdiction in order to maximise public utility. In other words, intra-jurisdictional efficiency takes into account only expenditures and utility within a specific jurisdiction. By contrast, inter-jurisdictional efficiency means that, among a number of interacting jurisdictions (such as those of a federal state or a 


\subsubsection{Can we fix the choice model?}

We can conclude by stating that a 'choice model' has a number of advantages, as it allows shareholders and directors to select the most efficient regulation. Yet, it also comes at a significant social cost and raises legitimacy concerns.

Can we imagine a compromise solution that keeps the advantages of the choice model and, at the same time, allows Member States to protect local non-adjusting creditors? Such a compromise would require carving out distribution rules from general insolvency law, ${ }^{103}$ for instance, granting the Member State of a debtor's centre of main interests the competence to govern creditors' priorities and clawback actions; additionally, the law governing employment and tenancy contracts should regulate the continuation of such contracts during insolvency proceedings, even if the general proceedings are governed by a different Member State selected by the debtor.

However, this solution would raise a number of problems due to the difficulty of disentangling redistributive insolvency rules from the rest of insolvency law. First of all, rules on creditors' priorities and asset exemptions are intertwined with workout proceedings. The main reason for this intertwining is that, in order to convince banks and other financial institutions to finance rescue proceedings, postinsolvency commencement lenders have to be prioritised over pre-existing creditors if the rescue attempt fails. ${ }^{104}$ Therefore, it seems extremely difficult to dissociate the rules on workout proceedings from those governing creditors' priorities. Similarly, avoidance actions related to fraudulent and preferential transfers can be difficult to carve out from general insolvency law. Such carve-outs would raise great uncertainties as to the applicable law and as to whether certain transactions can be avoided in case of a debtor's default. This uncertainty would ultimately raise the cost of credit or induce banks to ration it.

\subsection{Full harmonisation}

\subsubsection{The case for harmonising insolvency law in the European Union}

As we have seen, the choice model has a number of advantages, yet its social costs can be difficult to reduce. Therefore, policy makers need to explore the option of harmonising insolvency law in the EU.

union of states), the regulation minimises the cost suffered by all constituencies of all jurisdictions in order to maximise their collective demand for goods. See Robert P. Inman and Daniel L. Rubinfield, 'Federalism', in Boudewijn Bouckaert and Gerrit De Geest, eds., Encyclopedia of Law and Economics (Edward Elgar 1999), at p. 668, available at: $<$ http://encyclo.findlaw.com $>$.

103 In general, see Van den Bergh, supra n. 87, at p. 141.

104 Westbrook, Booth, Paulus and Rajak, supra n. 16, at pp. 143-145. 
Harmonised insolvency law would be a remedy against negative externalities produced by domestic legislations of Member States. Under the Insolvency Regulation, the law of the Member State of a debtor's COMI applies to assets and creditors located in other Member States, which can produce negative externalities and spillover effects. Such externalities would be even more pronounced by adopting the choice model and by replacing the COMI with the registered office. Following a public welfare approach, the solution to spillover effects is to grant the regulatory competence to the political body that is affected most by externalities. ${ }^{105}$ This approach therefore poses a strong argument in favour of harmonisation.

Nor is the principle of subsidiarity, which underpins EU law, an obstacle in the way of full harmonisation: the subsidiarity principle justifies harmonisation if a certain issue is better and more efficiently regulated at the EU level, due to the need to internalise negative externalities. ${ }^{106}$

By harmonising insolvency law, the highest possible authority, corresponding to the continental dimension of the debtor's activities, would regulate all defaults and thus internalise all negative externalities. ${ }^{107}$ Most importantly, EU policy makers would take into account the interests of non-adjusting creditors so as to gain their political support. In order to avoid spillover effects, creditors' priorities and asset exemption need to be harmonised as well. ${ }^{108}$ If identical rules applied throughout the EU, independently of the location of the assets or the company's registered office, regulatory arbitrage and forum shopping at the expense of creditors would be banned and all creditors would know in advance, and with certainty, which rules apply in case of their debtor's default.

\subsubsection{Drawbacks of full harmonisation}

However, harmonisation is not always the best option, even in regard to issues that produce significant externalities, if populations' preferences are heterogeneous across Member States. In these cases, smaller territorial units may be better

105 Thomas S. Ulen, 'Economic and Public-Choice Forces in Federalism', 6 George Mason Law Review (1997-1998), at p. 928: 'If the cost and benefits of an action, whether public or private, stray across jurisdictional lines, then the highest level of government that can fully internalize the costs and benefits of the action ought to take responsibility'; see also Inman and Rubinfield, supra n. 102, at p. 668; Liesbet Hooghe and Gary Marks, 'Unraveling the Central State, But How? Types of Multi-level Governance', 97 American Political Science Review (2003), at pp. 233-235; Josephine A.W. van Zeben, Competence Allocation and Regulatory Functioning, PhD dissertation, University of Amsterdam 2012, at pp. 38-51.

106 Aurélian Portuese, 'The Principle of Subsidiarity as a Principle of Economic Efficiency', 17 Columbia Journal of European Law (2011), at p. 238.

107 In favour of harmonisation, see Wessels and Fletcher, supra n. 4, at pp. 40-51.

108 To this end, harmonisation of certain private law rules might be necessary, because in some Member States insolvency priorities reflect general private law priorities. See, for instance, Veder, supra n. 62, at pp. 33-37 (comparing Dutch and German law). 
equipped to address local interests and needs. ${ }^{109}$ In general, a trade-off exists between efficiency gains produced by harmonisation and inefficiencies produced by the distance of the decision maker from people's heterogeneous preferences.

To find out whether this trade-off has positive or negative net effects with regard to insolvency law harmonisation, and in particular harmonisation of distributional rules, we should therefore look at the EU legislative mechanisms. The outcome is that full harmonisation of insolvency law is probably not feasible under the present structure of European institutions. In particular, the so-called 'democratic deficit' ${ }^{\prime 10}$ of European institutions and the dynamic of the EU decision-making process raise doubts as to whether the EU political bodies are appropriate to enact redistributive insolvency rules. Under the Treaty on the Functioning of the European Union, harmonisation instruments should be adopted following the ordinary legislative procedure ${ }^{111}$ which involves negotiations between the Commission which also has the power to submit the proposal - the Council and the European Parliament. This procedure mirrors the dual basis of democratic legitimacy in the institutions of the European Union, involving both the Member States and the citizens. ${ }^{12}$ Furthermore, the Council shall act by qualified majority vote, which is a complicated mechanism aimed at combining the need for big Member States to vote according to the size of their population with the need for small states not to be always outvoted. ${ }^{113}$ Therefore, the voting mechanism involves negotiations between Member States and induces them to seek broad consensus. ${ }^{114}$ As a result, harmonisation of distributional insolvency rules is likely to protect strong interest groups that are able to bargain at the highest EU level. ${ }^{115}$

109 See Alberto Alesina and Enrico Spolaore, 'On the Number and Size of Nations', 112 Quarterly Journal of Economics (1997), at p. 1030.

110 Paul Craig, 'Integration, Democracy and Legitimacy', in Paul Craig and Gráinne de Burça, eds., The Evolution of EU Law (Oxford University Press 2011), at pp. 30-40.

111 Article 294 TFEU.

112 See Alan Dashwood, Michael Dougan, Barry Rodger, Eleanor Spaventa and Derrick Wyatt, Wyatt and Dashwood's European Union Law (Oxford and Portland, Hart 2011), at pp. 7377; Jürgen Habermas, Zur Verfassung Europas (Berlin, Suhrkamp 2011), at pp. 62-74.

113 Pursuant to the new version of the qualified majority vote approved by the Lisbon Treaty, the majority requirements are: $55 \%$ of Member States, comprising at least 15 of them and representing at least $65 \%$ of the population; at least four Member States, however, can block the adoption of a Council decision: Article 16(4) Treaty on European Union. Until 31 October 2014, the former mechanism continued to apply (weighted supermajority of votes, majority of Member States representing $62 \%$ of the population: Article 205 Treaty Establishing the European Community). Between 1 November 2014 and 31 March 2017, the new qualified majority vote will apply, yet any Member State can request application of the old qualified majority criteria. The new qualified majority vote will enter into force as exclusive voting mechanism on 1 April 2017; see Article 16(5) Treaty on European Union and Article 3(2) Protocol on Transitional Provisions.

114 Dashwood, et al., supra n. 112, at p. 50.

115 Jonathan R. Macey, 'Federal Deference to Local Regulators and the Economic Theory of Regulation: Toward a Public-Choice Explanation of Federalism', 76 Virginia Law Review (1990), 
It may be expected that, if creditors' interests become sufficiently homogeneous throughout the EU, there will be no obstacle to full harmonisation of insolvency law. Presently, however, only banks, financial institutions and, perhaps, trade unions have sufficient influence to bargain at EU level. As a result, regarding distributional rules, one may reasonably expect that harmonised insolvency law will respect pre-insolvency entitlements and priorities (which is the primary interest of banks and sophisticated lenders, as we have seen above ${ }^{116}$ ), with the sole exception of employees' claims, which are likely to be prioritised. In other words, a fully harmonised EU insolvency law is likely to cancel all creditors' priorities, with the sole exception of those of employees, and, in this way, to alter national balances of security mechanisms and hierarchies of values and interests.

What would be Member States' reaction so such a scenario? The first possible reaction might be to convert the original nationally based creditors' priorities into statutory liens, namely rights in rem, which are likely to be respected even in case of full harmonisation of insolvency law. However, this strategy is useful only for debts somehow related to assets located in the territory of the same Member State, not for other credits. Therefore, in a fully harmonised insolvency regime, Member States that want to maintain the original hierarchy of interests and values will protect specific classes of creditors through welfare state mechanisms or other social securities, which can be either insurance-based or financed by taxpayers.

This outcome is not inefficient per se, yet reveals a significant obstacle in the way of full harmonisation. Indeed, harmonisation of distributional insolvency rules would indirectly influence social security strategies, which are considered as belonging to Member States' exclusive competence. ${ }^{117}$ This is the most fundamental obstacle to harmonisation of distributional rules.

\section{CONCLUSIONS}

This article has stressed that distributive insolvency rules, such as creditors' priorities, asset exemptions and set-off rights, complement national social security policies and are an expression of hierarchies of values and interests that, at present, are in the exclusive hands of Member States.

Under a 'choice model' for insolvency law, whereby companies can select the insolvency law they prefer, social preferences of the jurisdiction selected by the debtor will be imposed on stakeholders located in other Member States. This is a

at p. 271. Furthermore, harmonised rules are more difficult to amend than Member States' laws: William J. Carney, 'The Political Economy of Competition for Corporate Charters', 26 Journal of Legal Studies (1997), at p. 310.

116 Supra section 2.3.

117 See Nicole Bolleyer and Christine Reh, 'EU Legitimacy Revisited: The Normative Foundation of a Multilevel Polity', 19 Journal of European Public Policy (2012) p. 472. 
typical spillover effect, which can produce negative externalities and raises a significant question of political legitimacy. A possible solution to such externalities is unification or harmonisation of law, yet this solution also has weaknesses, for full harmonisation of insolvency law, including redistributive and socially sensitive rules, would alter existing balances in national social security mechanisms and strategies.

At the present stage of development of EU institutions, there is no optimal solution to the issue of power allocation in respect of bankruptcies, especially regarding rules on asset distribution. The reason is that this issue is not a matter of efficiency only: the 'optimal' solution has much more to do with politics and with the development of European integration. 